\title{
STRATEGI KAMPANYE POLITIK CALON ANGGOTA LEGISLATIF INCUMBENT DEWAN PERWAKILAN RAKYAT DAERAH DALAM MENGHADAPI PEMILU LEGISLATIF 2014 (Studi Kasus Partai Golkar di Kabupaten Mukomuko)
}

\author{
Oleh: \\ Y A N T O \\ Dosen Prodi Ilmu Komunikasi Fakultas Ilmu Sosial UNIVED Bengkulu
}

\begin{abstract}
This research is started from the legislative election that was held simultaneously throughout Indonesia, especially in the general election of 2014, the socialization and familiarization of each candidates to the public are important to do. Political campaign conducted by politicians will certainly look different to create a certain effect on a large number of audiences. In this case, the transformation in the level of knowledge or cognition and the transformation in attitude bring sympathy and then change audiences' behavior concretely. As seen from political points of view, new politicians and politicians who are incumbent have the same chance in winning votes in the general election. Because of that, incumbents have to prepare good strategies to win people's hearts in the legislative election. The researcher uses a qualitative approach using a case study to describe the case researched. The supporting theory used is a symbolic interaction theory, social consideration, and concepts regarding political campaign and political communication. In this study, the researchers involves three main informants, who are Ali Saftaini, Antonius Dalle, and Husni Thamrin as members of legislative assembly running for reactivating in the legislative election from the Golkar Party consisting of the first, second, and third constituencies. The results show that (1) The team is selected by the consolidation of family relationship that is a close family having good communication in everyday life, the big family of father and mother. The party chooses a very trustworthy person having emotional closeness and maintaining communication. (2) The target election identifies targets in constituencies and establishes permanent voters, constituent for five years, as well as establishes the vote center that is the place where the voters are domiciled, developed village and the big family, and have an interest which is community organizations, farmer groups, taklim, and youth organization in constituencies. (3) The message is delivered positively and negatively and is well packed. It mainly discusses comprehensively. (4) The tactic can be divided into two: direct communication and indirect communication. Direct communication can be implemented by face-to-face communication, visiting people, and "blusukan." Meanwhile, indirect communication can be implemented through media, newspaper, billboards, calendars, name cards, party and non-party T-shirts.
\end{abstract}

Keywords: political campaign, incumbents, legislative election 


\section{PENDAHULUAN}

Pemilihan Umum (pemilu) dalam perspektif Hak Azasi Manusia (HAM) pada hakekatnya merupakan pelaksanaan hak dasar politik rakyat yaitu hak untuk ikut serta menentukan arah dan masa depan kehidupan bersama dalam kehidupan bermasyarakat, berbangsa dan bernegara. Sebagai sarana demokrasi, pemilu akan memberi kesempatan kepada rakyat untuk memilih dan memberikan landasan keabsahan bagi wakil-wakil mereka yang duduk di parlemen atau pemerintahan.

Konsepsi pemilu merupakan hal yang paling ideal, namun kenyataannya pelaksanaan pemilu ternyata sangat dipengaruhi oleh struktur politik atau hubungan kekuasaan yang riil diantara kekuatan-kekuatan politik yang ada di dalam masyarakat, sehingga bisa berbeda esensi, tujuan dan teknis pelaksanaannya. Itu artinya, pemilu sebenarnya sangat tergantung pada sistem politik, kultur, cita-cita, kemauan politik dan rezim berkuasa.

Dalam pasal 77, UU No. 8

Tahun 2012 dinyatakan kampanye pemilu merupakan bagian dari pendidikan politik masyarakat dan dilaksanakan secara bertanggung jawab. Makna dari bertanggung jawab berarti kampanye dilaksanakan sesuai dengan undang-undang atau ketentuan yang berlaku. Atau bisa juga bermakna setiap janji dalam kampanye benar-benar harus dapat dipertanggung jawabkan nantinya setelah memperoleh jabatan atau kekuasaan.
Kampanye politik menurut Roger dan Storey dalam Heryanto dan Zarkasy (2012: 83), merupakan serangkaian tindakan komunikasi yang terencana dengan tujuan menciptakan efek tertentu pada sejumlah besar khalayak yang dilakukan secara berkelanjutan pada kurun waktu tertentu.

Komunikasi berperan penting dalam proses pencapaian tujuan politik, tujuan yang telah tersistematis dalam politik tidak akan tercapai maksimal tanpa adanya instrumen penghubung aktifitas politik itu. Antara komunikasi dan politik berkaitan erat dalam pencapaian tujuan yang akan di harapkan. Karena itu, setiap kampanye politik yang akan dilakukan oleh seorang caleg harus dilakukan dengan cermat, mulai dari perumusan konsep, penyusunan program dan strategi hingga taktik pelaksanaannya.

Caleg incumbent dipandang lebih mudah di bandingkan caleg yang baru, karena mereka bekerja sudah lama, sudah sosialisasi sejak lama, orang sudah banyak kenal. Popularitas, akses ke sumber daya kampanye, dan pengaruh atas birokrasi yang melekat pada pemegang kekuasaan, merupakan suatu modal politik yang besar bagi kandidat incumbent.

Bagi orang yang dikenal lebih luas, kampanye merupakan pengenalan lanjutan. Dalam kampanye masalah program akan menjadi perhatian serius kandidat karena menyangkut hajat orang banyak. Dalam hal ini tentu para politisi akan senantiasa membaca situasi dan kondisi masyarakat 
pemilih agar programnya di terima pasar. (Hirzi, 2009).

Dalam penelitian ini penulis mengambil subjek penelitian adalah calon anggota legislatif incumbent dari Partai Golkar, diantaranya; M. Ali Saftaini, SE. di dapil 1, Husni Thamrin. dapil 2, dan Antonius Dalle, SP. Didapil 3. Peneliti mengambil incumbent dari Partai Golkar dikarenakan bahwa dari sekian banyak incumbent yang kembali bertarung di pemilihan legislatif(pileg), hanya calon incumbent dari Partai Golkar ada disetiap daerah pemilihan (DAPIL).

Ada beberapa pertimbangan lagi yang peneliti lakukan sehingga menetapkan informan ini, diantaranya adalah ketiga incumbent ini merupakan orang penting baik dalam partai maupun di parlemen, seperti Ali Saftaini merupakan ketua DPD Golkar sekaligus menjabat ketua komisi I, dan Husni Thamrim merupakan ketua komisi II, selanjutnya Antonius Dalle sekjen di DPD Golkar menjabat sebagai wakil ketua komisi II dan anggota komisi III.

Berdasarkan temuan data dan informasi seperti yang tercantum di atas, maka menarik bagi penulis untuk diteliti lebih lanjut melalui mekanisme ilmiah tentang kampanye politik maupun upaya-upaya yang dilakukan oleh calon anggota legislatif incumbent Partai Golkar Mukomuko. Dalam pemilihan legislatif (pileg) Tahun 2014.

\section{METODE PENELITIAN}

Dalam penelitian ini penulis menggunakan metode studi kasus yang menggambarkan atau mendeskripsikan kasus yang sedang diteliti, menentukan data yang akan dikumpulkan itu relevan, atau apa yang seharusnya dikerjakan sehubungan dengan data yang telah terkumpul.

Subjek penelitian adalah individu, benda, atau organisme yang dijadikan sumber informasi yang dibutuhkan dalam pengumpulan data penelitian. Dalam penelitian ini subjek yang dijadikan informan atau sembernya adalah, calon anggota legislatif (caleg) incumbent partai Golkar Kabupaten Mukomuko, diantaranya: M. Ali Saftaini, SE. di dapil 1, Husni Thamrin. dapil 2, dan Antonius Dalle, SP. Didapil 3.

Teknik pengumpulan data dalam penelitian ini adalah penulis menggunakan metode pengumpulan data sebagai berikut: Obeservasi Metode observasi ini penulis gunakan untuk mengadakan observasi pendahuluan, pengamatan langsung mengenai kegiatan yang berkaitan dengan strategi kampanye politik calon anggota legislatif incumbent DPRD Mukomuko pada pemilu legislatif 2014 Mukomuko. Wawancara. Metode pengumpulan data yang dilakukan melalui wawancara untuk mendapatkan informasi secara langsung dengan mengungkapkan pertanyaan pertanyaan pada para responden. Untuk mendapatkan informasi yang relatif lebih objektif, maka wawancara di sini dilakukan terhadap satu orang responden/individu, yang termasuk responden yang sekiranya dapat membantu peneliti untuk memberikan informasi dan untuk 
melengkapi data yang diperoleh melalui observasi.

Sedangkan pada penyajian data yang diartikan sebagai sekumpulan informasi tersusun yang memberikan kemungkinan adanya penarikan kesimpulan dan pengambilan tindakan, selain itu juga dengan melihat penyajian-penyajian penulis akan dapat memahami apa yang sedang terjadi dan apa yang harus dilakukan. Kegiatan analisis ketiga yang penting adalah menarik kesimpulan dan verifikasi. Kesimpulan-kesimpulan "final" mungkin tidak muncul sampai pengumpulan data terakhir, tergantung pada besarnya kumpulankumpulan catatan lapangan, observasi, pengkodeannya, penyimpangan, dan kecakapan penelitian.

\section{HASIL PENELITIAN DAN PEMBAHASAN}

\section{Tim Kampanye Calon Anggota} Legislatif Incumbent

Tim Sukses adalah orang yang sangat berpengaruh dalam usaha pemenangan calon atau kandidat, diutamakan orang yang sudah memiliki kemampuan secara manejerial serta loyalitas dan tidak dapat diragukan serta mempunyai Visi dan Misi Jangka panjang untuk orientasi dalam pemenangan calon, tanpa mengenal waktu dalam melaksanakan kegiatan, dengan kata lain bahwa tim sukses adalah pemegang tugas dan tanggung jawab dalam Pemilihan Umum.

Mengingat mereka adalah orang kepercayaan kandidat, untuk itu perlu kehati-hatian dalam melakukan rekrutmen untuk bisa masuk menjadi tim kampanye, untuk merealisasikan program kerja serta dapat mensosialisasikan Visi dan Misi calon, agar dapat dipahami secara jelas oleh masyarakat pemilih suara, ada beberapa ajuan yang dapat dilakukan dalam merekrut tim.

Sesuai dengan pengamatan yang peneliti lihat yang ada dilapangan meskipun orang yang dipilih adalah keluarga ataupun satu organisasi namun, tidak semua orang bisa bergabung dalam tim ada beberapa pertimbangan sebelum ia bisa bergabung dengan tim pemenangan dalam menjalankan kampanye.

Melihat dari itu semua dapat memahami betapa pentingnya sifat selaktifitas dalam merekrut orang untuk masuk kedalam tim, dari apa yang dijelaskan diatas dapat peneliti pahami bahwa yang harus dilakukan adalah: memiliki hubungan baik, orang yag benar-benar berpengaruh dalam desa, kedekatan secara emosional, pintar ngomong, bagus dalam pergaulan, keluarga besar, dan masih memiliki nama baik di mata masyarakat, orang bisa dipercaya, dan yang terpenting adalah orang yang bisa bekerja sama dan mau meluangkan waktunya.

Selanjutnya tidak kalah penting setelah tim kampanye terbentuk maka langkah selanjutnya adalah menetukan fungsi dan tugas mereka dimasyarakat, karena mengingat mereka adalah penyambung dan mewakili kandidat dimasyarakat ada beberapa peran dan fungsi tim yang dapat kita lakukan sesuai temuan penulis dilapangan.

Sesuai dengan pengamatan yang peneliti lakukan dan perbincangan yang dilakukan, 
memang banyak yang menawarkan akan memberikan suara $10-50$ suara dalam pemilihan nanti, dan itu ditanggapi saja dengan baik, sejauh pengamatan peneliti tidak begitu antusias mereka (kandidat) merespon hal itu, yang sangat sering terjadi ketika orang menawarkan suara sekian yang akan muncul waktu pemilihan tidak akan sama, terlepas dari itu semua dalam tim memang tidak ada yang diberikan fasilitas yang sepesial hanya saja mereka diberi uang operasional, karena mereka juga paham betul bagaimana tim bergerak dilapangan, tidak semua hal bisa didapatkan dengan gratis.

\section{Sasaran Calon Anggota Legislatif Incumbent}

Pemilih atau konsituen yang terlalu heterogen serta bervariatif dalam tuntutan kebutuhan dan keinginannya maka benar-benar perlu mengkelompokkan konsituen, lalu memilih dan menetapkan sasaran. Dengan adanya hal ini, maka pergerakan yang akan dibuat akan lebih terbantu untuk mengidentifikasi peluang dengan lebih baik, dengan demikian kandidat atau calon legislatif dapat mengembangkan keinginan dan maksud tujuan dengan tepat.

Sebagai langkah awal memilih kelompok audiens atau penerima pesan sasaran. Kelompok penerima pesan sasaran harus dapat diidentifikasi dengan karakteristik yang spesifik dan jelas, sehingga memudahkan untuk menentukan program yang ingin disampaikan, dan lagi saat memilih audiens sasaran, disana akan ditemukan peluang yang sangat luas dan beranekaragam, sehingga perlu menetapkan dengan cermat dalam menentukan sasaran.

Melihat yang telah disampaikan di atas, dapat peneliti uraikan beberapa kreteria yang bisa kita gunakan dalam menetapkan sasaran diantaranya, orang yang belum menentukan pilihan, orang yang memiliki kepentingan, tokoh masyarakat, lalu orang yang memiliki keluarga besar yang berpengaruh dilingkungan tersebut, dan selanjutnya anggota organisasi. Hal ini disebabkan masih banyak warga-warga yang masih ngambang yang belum menentukan pilihan oleh karena itu harus benar-benar cermat melihat itu semua.

\section{Pesan Yang Akan Disampaikan Anggota Legislatif Incumbent}

Dalam kajian komunikasi politik strategi dalam pengemasan pesan sangatlah penting, karena peran dalam pengemasan pesan kita akan mengarahkan cara masyarakat memaknainya, tentu harus sesuia denga isu-isu yang sedang berkembang dalam masyarakat, (Firmanzah, 2013:261).

Pesan merupakan

keseluruhan dari apa yang disampaikan oleh komunikator. Pesan seharusnya mempunyai inti, pesan atau tema sebagai pengaruh di dalam usaha mencoba mengubah sikap dan tingkah laku komunikan. Dalam penyampaian pesan harus benar-benar selektif dalam menyampaikan informasi yang akan diberikan kepada konsituen karena itu bisa saja menjadi bumerang bagi kandidat itu sendiri. Ketika seseorang akan terjun dalam masyarakat, mereka harus membawa informasi awal terhadap warga yang 
itu diharapkan akan bisa memobilisasi warga, sesuai dengan harapan. Ketika akan menyampaikan informasi kepada masyarakat yang menjadi konsituen, banyak informasi yang dapat sampaikan, apalagi penyampaian yang dilakukan secara langsung, berdialog dengan warga, mulai dari pemahaman betapa pentingnya perwakilan yang duduk di legislatif atau pemerintahan, dan kinerja pemerintah saat sekarang ini, serta program-program yang berjalan saat ini memang ada keikut sertaan dalam menetapkan program itu.

Terlepas dari itu memberikan sikap netral terhadap pemerintah sangat diperlukan, maka tidak jarang diangkat tentang bagaimana pemerintah dalam hal ini eksekutif menzholimi warga, lalu menyampaikan bagaimana pihakpihak tertentu yang tidak menginginkan keberadaan sang kandidat, sehingga benar-benar memposisikan diri sebagai orang yang terzholimi. Selanjutnya akan menyampaikan bagaimana dan apa yang akan dilakukan nanti, namun yang terpenting dari itu semua harus menyampaikan informasi bagaimana cara menggunakan hak suara, dan apa manfaat yang akan didapatkan.

Selanjutnya sesuai dengan pengamatan dan temuan yang penulis temukan ketika mereka bertemu dengan warga yang sangat sering mereka sampaikan adalah cara mencoblos dengan baik dan benar dan langkah yang akan mereka lakukan ketika menjabat sebagai anggota legislatif.

Citra politik yang menarik dan dianggap penting oleh masyarakat akan mendorong pemilih untuk menjatuhkan pilihan politiknya kepada calon tersebut, hal ini akan bisa terwujud ketika bisa mengolah semua informasi yang didapat dan diangkat menjadi sebuah isu politik yang akan kita sampaikan kemasyarakat secara umum.

\section{Saluran Yang Digunakan Dalam Penyampaian Pesan}

Strategi adalah pendekatan secara keseluruhan yang berkaitan dengan pelaksanaan gagasan, perencanaan, dan eksekusi sebuah aktivitas dalam kurun waktu tertentu. Dan memiliki taktik untuk mencapai tujuan secara efektif untuk melaksanakan strategi. Jika manajemen sudah merumuskan tujuan dan strateginya, maka ia berada dalam posisi untuk menentukan taktik.

Tujuannya tidak lain untuk membantu konsituen lebih memahami solusi yang ditawarkan dan menjalin relasi dengan pemilih jika bisa berhubungan terus dengan mereka (konsituen), maka akan bisa mengkomunikasikan manfaat dari apa yang ditawarkan, sehingga pemilih atau konsituen akan mengambil keputusan dengan tepat.

\section{PEMBAHASAN}

Saat sekarang masing-masing partai maupun kontestan individu memiliki peluang yang sama untuk memenangkan persaingan dalam perebutan suara masyarakat melalui pemilu, persaingan yang terjadi antara partai politik dan kontestan merupakan ciri khas yang meronai dunia politik sekarang ini, maka sangat dibutuhkan strategi yang matang untuk memenagkan pemilihan umum (pemilu). 
Terkait dengan fenomena yang telah diuraikan di atas memang zaman menuntut untuk melakukan pendekatan-pendekatan baru agar bisa berkembang, seperti yang telah diterapkan oleh narasumber dalam penulisan ini adalah calon anggota legislatif incumbent Partai Golkar di Kabupaten Mukomuko dalam hal ini: Ali Saftaini, Antonius Dalle dan Husni Thamrin.

Kampanye tidak akan dapat dilakuakan tanpa ada interaksi dengan masyarakat ketika partai politik memiliki komitmen dalam melakukan kampanye jangka panjang, interaksinyapun harus dilakukan secara permananen. (Firmanzah, 2012:292). Hal ini juga dikarenakan berubahnya kondisi sosial masyarakat membuat informasi yag dibutuhkan partai politik ikut berubah, tentu tidak ada pilihan lain selain melakukan interaksi, seperti yang diketahui dalam interaksi terdapat proses pertukan informasi, hal ini bukan hanya sebagai informasi bagi partai tetapi juga melihat sejauh mana partai dan kandidat bisa diterima di masyarakat.

\section{Tim Kampanye}

Mengingat tim kampanye adalah orang kepercayaan kandidat, untuk itu perlu kehati-hatian dalam melakukan rekrutmen untuk bisa masuk menjadi tim kampanye, untuk merealisasikan program kerja serta dapat mensosialisasikan Visi dan Misi calon, agar dapat dipahami secara jelas oleh masyarakat yang memiliki hak suara.

Penentuan sebuah tim tidak bisa asal merekrut orang untuk masuk dalam tim, mengingat tim yang akan lebih intens bekerja, selaras dengan temuan peneliti di lapangan, dan pengamatan peneliti setidaknya ada beberapa langkah yang bisa dilakukan harus melakukan observasi awal dimasyarakat melihat kebutuhan, karena sesuai dengan yang apa yang penulis temukan di lapangan, ada beberapa desa yang tidak bisa kita buat tim, karena di desa tersebut semua warga telah menjadi bagian, ada juga yang tidak ada tim karena melihat lawan politik yang ada di sana, terlepas dari itu secara umum kita memerlukan tim disetiap desa. Dan dalam penentuan tim itupun dimulai melalui hubungan kedekatan, dalam hal ini keluarga, baik keluarga dekat maupun jauh, orang yang satu organisasi dan teman sepermainan, terlebih lagi dengan hubungan sesama partai. Berangkat dari itu semualah sehingga tim kita bisa berkembang.

Mengingat mereka akan menyampaikan program-program yang akan dibuat oleh kandidat, dan diharapkan program itu sejalan dengan harapan masyarakat, ada kesamaan persepsi yang ingin dicapai oleh kandidat dengan konsituen. Menurut Sharif, dalam teori pertimbanga sosial (Venus,2012:119) ada tiga rujukan yang digunakan seseorang untuk merespon atau stimulus yang dihadapi. Ketiganya merupakan bagian yang saling terkait yang pertama disebut latitude of acceptance (rentang atau wilayah penerimaan) yang terdiri dari pendapat-pendapat yang masih dapat diterima dan ditoleransi, bagian kedua disebut latitude of rejection (rentang penolakan) dan yang terakhir disebut latitude of 
noncommiment

(rentang

ketidakterlibatan) yang terdiri dari pendapat atau pesan-pesan persuasif yang tidak kita tolak dan tidak kita terima.

Dengan demikian tim dituntut untuk bisa menyamakan persepsi yang berkembang di masyarakat, karena apabila tidak sesuai dengan apa yang terjadi di lapangan bisa saja mereka ditolak. Dan mengingat bukan diri mereka saja yang akan mereka bawa, karena posisi mereka sejajar dengan kandidat dengan diberikan kepercayaan penuh, sehingga diharapkan benar-benar bisa mewakili diri sang kandidat.

Perloff. (Venus 2012: 43-44), Mengatakan "Pesan yang diorganisasikan dan disampaikan dengan baik belum tentu cukup untuk mempengaruhi khalayak, tentu diperlukan juga komunikator yang terpercaya untuk menyampaikan pesan tersebut". Karena alasan ini maka kredebilitas komunikator merupakan hal yang harus diperhatikan agar ia bisa menjadi pembawa pesan yang dapat dipercaya.

Mereka diberi tugas untuk menggiring masyarakat memilih calon atau kandidat tertentu dalam pemilihan legislatif, tim yang dibuat benar-benar bisa bekerja, namun hal tersebut bukanlah menjadi tanggung jawab yang besar yang diemban oleh tim, hal ini bisa terlihat bagaimana kandidat tidak pernah memporsil dan menargetkan suara yang harus mereka dapat, jadi jelas tidak ada tekanan disana. Setelah mengamati di lapangan dapat dikatagorikan yang bisa masuk dalam anggota tim pemengan mulai dari keluarga, partai dan ormas dan tidak semua yang ada di dalamnya bisa masuk dalam tim tentu yang paling dilihat adalah kredebilitas, tidak cukup itu saja daya pengaruh yang dimiliki oleh orang tersebut juga sangat penting di bawah ini peneliti menggambarkan dengan model untuk menjelaskan secara rinci:

\section{Sasaran Kampanye}

Sebagai Langkah awal memilih kelompok audiens atau penerima pesan sasaran. Kelompok penerima pesan sasaran harus dapat diidentifikasi dengan karakteristik yang spesifik dan jelas, sehingga memudahkan untuk menentukan program yang ingin disampaikan, dan lagi Saat memilih audiens sasaran, kita akan menemukan peluang yang sangat luas dan beranekaragam, sehingga perlu menetapkan dengan cermat dalam menentukan sasaran. maka membutuhkan serangkaian defenisi terhadap serangkaian yang harus dirumuskan, sehingga mempunyai tujuan dan sasaran yang jelas.

Sesuai dengan model Ostergaart bahwa yang harus dilakukan pertama harus dilakukan sumber kampanye (campaign makers atau decision maker) adalah mengidentifikasi masalah faktual yang dirasakan. Selanjutnya dicari hubungan sebab akibat (cause and relationship) dengan fakta-fakta yang ada. (Venus,2012:15).

Sesuai dengan temuan peneliti di lapangan incumbent secara hitunghitungan lebih mudah menentukan sasaran mereka, sasaran utamanya adalah pemilih tetap, dalam artian konsituen yang telah bersama dengan mereka selama lima tahun belakangan ini, namun hal itu tidak 
juga bisa menjamin dia akan mudah melaju sebagai calon legislatif seperti yang terjadi di lapangan, mengingat orang yang mencalonkan diri menjadi anggota legislatif tidak sedikit, sehingga mereka benar-benar harus teliti dengan hal itu.

Dapat peneliti gambarkan bahwa hal yang pertama dilakukan adalah mulai dengan melakukan identifikasi, menetapkan pusat suara dan merangkul kembali pemilih tetap yang dimiliki dalam hal ini orang yang bersama dengan kita dan partai selama ini, dan selanjutnya yang memiliki kepentingan, seperti organisai masyarakat (ormas). Di bawah ini peneliti gambarkan dalambentuk model:

\section{Pesan Politik}

Idealnya kampanye politik merupakan proses penyampaian pesan politik, salah satu fungsinya memberikan pendidikan politik, dari kampanye ini diharapkan dapat meyakinkan massa, oleh karena itu partai ataupun politisi dituntut menemukan cara-cara paling efektif untuk merekrut sebanyak-banyak nya massa, (Muhtadi, 2008:145).

\section{Saluran Penyampaian Pesan Politik Melalui Media Komunikasi}

Kampanye menggabungkan partisipasi aktif antara yang melakukan kampanye (peserta pemilihan umum) dan pemberi suara (pemilih), pelaku kampanye akan berusaha mengatur kesan kepada pemberi suara tentang diri mereka dengan menggunakan berbagai cara. Taktik atau media komunikasi penyampaiaan pesan menjadi hal yang sangat penting tujuannya tidak lain untuk membantu konsituen lebih memahami solusi yang ingin ditawarkan dan menjalin relasi dengan pemilih. Apabila bisa berhubungan terus dengan mereka (konsituen), maka bisa mengkomunikasikan manfaat atau jasa dari yang ditawarkan, sehingga pemilih atau konsituen akan mengambil keputusan dengan tepat sesuai dengan harapan penyampai pesan.

Selanjutnya peneliti ingin menggambarkan bagaimana langkah kongkrit yang bisa dilakukan ketika caleg incumbent kampanye sesuai dengan temuan peneliti dilapangan, dengan menyelaraskan saluran yang digunakan media dan non media dimulai dengan tetap menjaga hubungan baik dengan keluarga, dan melakukan hubungan secara langsung atau tatap muka, sampai mengunjungi rumah konsituen, dan penggunaan media, seperti surat kabar, spanduk baju partai dan penggunaan kalender.

Dari penjelasan di atas dapat penulis katakan bahwa simbol adalah objek sosial yang digunakan untuk merepresentasikan apa-apa yang memang disepakati bisa direpresentasikan oleh simbol tersebut. Bahwa Individu sebagai produsen sekaligus konsumen atas simbol tidak hanya merespon simbol secara pasif, tetapi juga secara aktif menciptakan dan menciptakan kembali dunia tempat dia bertindak berdasarkan realitas yang datang.

Fakta Setelah Pemilihan Legislatif Setelah penulis melakukan penelitian dari ketiga narasumber sangat jelas terlihat bagaimana perbedaan diantara ketiganya: 


\begin{abstract}
Husni Thamrin, sesuai dengan pengamatan peneliti dilapangan, ia sosok orang yang rajin, disiplin dan antusias dengan tugas yang ia emban, karena ini tercermin dalam kesehariannya, ia selalu hadir dikantor DPRD Mukomuko dan sangat jarang di rumah di siang hari, dan cenderung sangat sepi di rumah tersebut, ia termasuk orang yang jarang menemui warga kecuali hari libur baru ia berkunjung ke Desa-Desa. Dan di malam harinya barulah ia didatangi oleh warga, menurut penelaian penulis apa yag dilakukan oleh Husni Thamrin memang tidak melakukan pola kampanye seperti layaknya yang harus dilakukan, ia menganggap apa yang telah dilakukan bagian dari kampanye, dengan mengedepankan figur, nama baik yang telah ia buat selama ini, sesuai dengan tuntutan zaman melihat konsituen yang ia hadapi lebih cendrung kepada apa yang mereka dapat, sedangakan Husni tidak ada langkah kongkrit yang ia tawarkan untuk masyarakat, sehingga ia gagal menduduki kursi legislatif.
\end{abstract}

\section{PENUTUP}

\section{Kesimpulan}

Berdasarkan hasil penelitian yang dilakukan, maka dapat dsimpulkan sebagai berikut, Pembentukan tim kampanye yang dilakukan caleg incumbent dengan cara menjaga konsolidasi hubungan keluarga, yaitu keluarga dekat yang selalu melakukan komunikasi baik dalam keseharian, dalam hal ini keluarga ibu dan ayah. Selanjutnya organisasi kepemudaan, kelompok tani, majelis ta'lim, pelibatan tokoh masyarakat setempat atau tokoh adat, dan organisasi sayap dari partai. Dengan beberapa pertimbangan, benar-benar berpengaruh di daerah target pemenangan, bagus dalam pergaulan dan pintar berbicara, juga mempunyai reputasi dan nama baik di tengah masyarakat. Sesama partai diambil orang yang bisa dipercaya, yaitu orang yang memiliki kedekatan secara emosional yang selalu menjaga komunikasi.

\section{Saran}

Dalam melakukan kampanye politik partai politik mempunyai posisi yang berpengaruh, maka hendaknya menjalankan fungsinya untuk memberikan pendidikan politik yang baik pada masayarakat, salah satunya dengan merekrut kader-kader yang benar-benar mempunyai kemampuan untuk mengayomi masyarakat, mengingat partai politiklah wadah untuk itu semua

\section{DAFTAR PUSTAKA}

Andrian Charles F. 1992. Kehidupan Politik dan Perubahan Sosial, Penerjemah Luqman Hakim, Yogyakarta, PT Tiara Wacana

Ardianto, Elvinaro dan Bambang Qnees. 2007. Filsafat Ilmu Komunikasi. Bandung, Simbiosa Rekatama

Metodologi Penelitian Untuk Public Relation Kuantitatif Dan Kualitatif. Bandung, Simbiosa Rekatama Media 
Arikunto, Suharsimi. 2006. Prosedur Penelitian. Bandung, Rosda Karya,

Bryson. Jhon M. 2003. Perencanaan Strategi Bagi Organisasi Soial, Terjemahan M. Miftahuddin. Yogyakarta, Pustaka Pelajar

Budiardjo Miriam. 2008. DasarDasar Ilmu Politik. Jakarta, PT Gramedia Pustaka 1998. Partisipasi Dan Partai Politik. Jakarta, Yayasan Obor Indonesia

Bungin, Burhan. 2003. Metode Penelitian Kualitatif. Jakarta, PT Raja Grafindo Persada

Cangara Hafied. 2009. Komunikasi Politik, Konsep Teori Dan Strategi. Jakarta PT Rajagravindo Persada

Effendy, Onong Uchana. 1998. Ilmu Komuniksi, Teori dan Praktek. Bandung, PT. Citra Aditya Bakti

Firmanzah. 2013. Marketing Politik. Jakarta, Pustaka Obor Indonesia

Harun, Rochajat dan Sumarno.2006. Komunikasi Politik Sebagai Pengantar. Bandung, Mandar Maju

Heryanto, Gun Gun, dan Rumaru Shulhan. 2013. Komunikasi Politik Sebuah Pengantar. Bogor, Ghalia Indonesia
Irwa. 2012. Public Relations

Politik. Bogor, Ghalia Indonesia

Imawan Riswandha. 1997. Membedah Politik Orde Baru Yogyakarta, Pustaka Pelajar

Iqbal, M. 2013. Peraturan KPU Kampanye Caleg Perpol

Isjwara F. 1995. Pengantar Ilmu Politik. Bandung, Bina Cipta

Jemadu, Aleksius. 2008. Perpolitikan Global dalam Teori dan Praktik. Jogyakarta

KPU. 2013. Pedoman Pelaksanaan Kampanye. Jogjakarta

Lameande, Lanny. 2012. Defenisi, Jeni-Jenis, Perbedaan Kampanye dan Propoganda dan Iklan

Liliweri, Alo. 2011. Komunikasi (serba ada serba makna). Jakarta, Prenada Media Group

Miles, B. Matthew \& Michael A, Hubberman. 1992. Analisis Data Kualitatif. Jakarta, Universitas Indonesia

Moleong, J Lexy. 2008. Metode Penelitian Kualitatif. Edisi Revisi. Bandung, PT. Remaja Rosdakarya.

Muhtadi, Asep Saeful 2008. Komunikasi Politik Indonesia (Dinamika Islam Politik Pasca Orde Baru). Bandung, PT Remaja Rosda Karya 
Mulyana, Deddy. 2007. Ilmu Komunikasi Suatu Pengantar. Bandung, PT Remaja Rosdakarya 2008. Metode Penelitian Komunikasi. Bandung, PT Remaja Rosdakarya 2003. Metodologi Penelitian Kualitatif: Paradigma Baru Ilmu Komunikasi Dan Ilmu Sosial Lain. Bandung,PT Remaja Rosdakarya
Nimmo, Dan. 1999. Komunikasi politik: komunikator, pesan dan media. Bandung, PT. Remaja Rosdakarya

2006. Komunikasi Politik: Khalayak dan Efek. Bandung, PT. Remaja Rosdakarya 